\title{
Discontinuous History and Magical Realism: A Foucauldian Reading of Kazuo Ishiguro's The Buried Giant
}

\section{Süreksiz Tarih ve Büyülü Gerçekçilik: Kazuo Ishiguro'nun Gömülü Dev Adlı Romanının Foucaultcu Bir Okuması}

\author{
Baysar TANIYAN ${ }^{1}$ (i)
}

${ }^{1}$ Assist. Prof., Pamukkale University, Faculty of Science and Letters, Department of English Language and Literature, Denizli, Turkey

ORCID: B.T. 0000-0002-2843-8835

\section{Corresponding author: \\ Baysar TANIYAN, \\ Pamukkale Üniversitesi, Fen Edebiyat \\ Fakültesi, İngiliz Dili ve Edebiyatı Bölümü, Denizli, Türkiye \\ E-mail: btaniyan@pau.edu.tr}

Submitted: 26.01 .2021

Revision Requested: 04.05.2021

Last Revision Received: 18.05.2021

Accepted: 06.09.2021

Citation: Taniyan, B. (2021). Discontinuous history and magical realism: A Foucauldian reading of Kazuo Ishiguro's The Buried

Giant. Litera, 31(2), 525-546.

https://doi.org/10.26650/LITERA2021-868869

\begin{abstract}
Michel Foucault's archaeological approach to history contests Hegelian understanding of evolutionary and progressive history which presupposes an ultimate arrival at a perfect form of society. For Foucault, history does not follow a linear, dialectical line within a cause-and-effect relationship. Each historical period has its own conditions of truth and between these periods, there are breaks, twists, ruptures and discontinuities determined by power relations in that society. These historical transformations occur following a change in épistèmé which connotes to the available set of knowledge produced by discursive practices in a particular period. Within this context, this study aims to analyse historical discontinuities in Kazuo Ishiguro's magical realist novel, The Buried Giant (2015). In the novel, by benefiting from generic potentials of magical realism, and effectively exploiting the medieval romance, Ishiguro creates a quasimythological historical account of the Anglo-Saxon period. In his version, King Arthur makes Merlin perform a spell on a dragon. Due to the spell, the Britons and the Saxons suffer memory loss which causes historical discontinuities. Moreover, while the spell confines the people into a perpetual here and now, it grants Arthur absolute political power. The study will focus on these discontinuities and present a Foucauldian reading of the text. The study will also theoretically connect Foucault's discontinuous history with magical realism, which may broaden our understanding of Ishiguro's text.
\end{abstract}

Keywords: Kazuo Ishiguro, The Buried Giant, magical realism, history, discontinuity

öz

Michel Foucault'nun tarihe arkeolojik yaklaşımı, nihayetinde mükemmel bir topluma ulaşmayı öngören Hegelci evrimsel ve ilerici tarih anlayışına itiraz eder. Foucault, tarihin, neden-sonuçilişkisi içinde doğrusal, diyalektik bir çizgi izlediği düşüncesinde değildir. Her tarihsel dönemin kendine özgü hakikat koşulları vardır ve de bu dönemler arasında o toplum içerisindeki iktidar ilişkileri tarafından belirlenen kırılmalar, kopmalar ve süreksizlikler vardır. Bu tarihsel dönüşümler, belirli bir dönemde söylemsel pratikler tarafından üretilen mevcut bilgi dizisi olarak tanımlanan epistemenin değişiminin sonucu olarak ortaya çıkar. Bu bağlam içerisinde, makale Nobel ödüllü Ingiliz yazar Kazuo Ishiguro'nun büyülü gerçekçi romanı Gömülü Dev'deki (2015) tarihsel süreksizlikleri incelemeyi amaçlamaktadır. Romanda Kazuo Ishiguro, büyülü gerçekçilik 
türünün ona sunduğu imkanlardan ve ortaçağ romanslarından etkili bir şekilde faydalanarak Anglo-Sakson döneminin yarı mitolojik bir tarihi versiyonunu yaratır. Ishiguro'nun tarih versiyonunda, Kral Arthur'un isteğiyle Merlin bir ejderhaya büyü yapar. Bu büyünün ortaya çıkardığı etkiyle hem Britonlar hem de Saksonlar, tarihsel süreksizliklere neden olan hafıza kaybına uğrarlar. Dahası, Merlin tarafından yapılan bu büyü, bu iki halkı ebedi şimdiye ve buradaya hapsederken, Kral Arthur'a ise mutlak ve sorgulanamayan bir siyasal iktidar inşa etme olanağı sunar. Çalışma, bu süreksizliklere odaklanarak metnin Foucaultcu bir okumasını sunmayı amaçlamaktadır. Bu çalışma aynı zamanda Michel Foucault'nun süreksiz tarihi ile büyülü gerçekçilik türü arasında kuramsal bir bağ kurarak ıshiguro'nun metninin daha iyi anlaşımasını sağlayacaktır.

Anahtar Kelimeler: Kazuo Ishiguro, Gömülü Dev, büyülü gerçekçilik, tarih, süreksizlik 


\section{Introduction}

Man is a rational animal. It is therefore instinctual that we want to rationalize everything surrounding us. Whenever we see an effect, we look for its cause, because the opposite is unthinkable. Since the Age of Enlightenment when man began to put everything under the scrutiny of his reason and intellect, we have been looking for regularities, similarities, recurrent patterns and forms, consistencies, relevance in every sphere of life. We have been more concerned with tradition, heritage, and lineage because, as subjects governed by reason, we identify, locate, and position ourselves accordingly. All of these require 'continuity'. Likewise, history, especially since the Enlightenment, has been regarded as a seamless narrative, one event causing another. This implies Hegelian understanding of progressive and evolutionary or dialectic history, or Marxist understanding of the historical process that will eventually terminate in a classless society. As a direct outcome of this understanding, in history of literature classes, students are taught the successive literary periods as a response or a reaction to one another. Within this understanding, while a historical era is the ultimate result of the earlier one, it also paves the way for the next one.

The continuous, progressive understanding of history, of course, has met challenges. Michel Foucault has provided the most important, complex, comprehensive, and puzzling of all. In his archaeological and genealogical approaches, Foucault proposes a discontinuous history. Rather than working on similarities and connections, he tries to lay out ruptures, breaks, transformations, and discontinuities. Rather than trying, in a humanist way, to domesticate the past by relating it to the present, he reveals, in an anti-humanist manner, "how different, threatening, distant the past was" from the present (Poster, 1984. p. 74). Moreover, for him, "history is another form of discourse and knowledge at the same time", which has an intrinsic relationship with power and control (Poster, 1984. p. 75). Within this theoretical context, this article aims to analyse Kazuo Ishiguro's The Buried Giant (2015) which presents, in a magical realist way, a discontinuous individual and collective quasi-historical narrative of the Anglo-Saxon period in British history. In relation to the concept of discontinuity, a Foucauldian reading of the novel will be proposed using other concepts; power, knowledge, and subjugated knowledge. The article will also build a theoretical link between magical realism and Foucauldian understanding of history. This link has the potential to offer new insights into the relationship between magical realism and history, and into the way Ishiguro deals with the themes of memory and history. Moreover, by drawing from 
the Arthurian romances, a genre that intermingles with history and functions to consolidate British national identity historically, Ishiguro creates a political context in which to latently discuss the migrant crisis and border security, and, in relation to that, the fluidity of national identities.

\section{Magical Realism and Discontinuous History}

Yugin Teo (2014) defines Kazuo Ishiguro as a novelist who customizes literary genres to create "a metaphorical framework" to analyse his favourite subjects (pp. 88-89). Set in a post-Arthurian period, The Buried Giant represents Ishiguro's venture into the magical realist form. A lengthy debate concerning the definition of magical realism has taken place since Franz Roh coined the term in the 1920s (Esen, 2018, pp. 7-20; Tutan, 2016). Despite disagreements, there are shared fundamental points on which a common ground can be formed. For instance, magical realism is political and historical. It voices a protest over the dominant codes, binaries, knowledge, organization, and historical understandings inherited from the Enlightenment philosophy. There is also a protest lodged against the Realist fiction as the cultural outcome of that Cartesian philosophy. Studying magical realist texts of Grass, Süskin, Kundera, Garcia Marquez and Fuentes, Wendy B. Faris (2004) concludes that magical realist texts bring together two incompatible perspectives, magical and realist, in order "to deconstruct the univocal narrative authority that characterizes much realistic fiction" (pp. 142). Faris further indicates that these texts are deconstructive as they aim to question "totalitarian discourses of all kinds, including that of much modern historical narrative" (2004, p. 142). In other words, magical realist texts provide a new outlet for those suppressed by the totalitarian discourses, for those excluded from the continuous history, and for those cast into the periphery. These texts revisit past events, assess existing historical narratives to find silences, discrepancies, ruptures, contingencies, and discontinuities that betray causality, linearity, and progress.

From this perspective, magical realism can be aligned with postmodernist literature in its reaction against totality, grand narratives, uniformity, and singularity (Hutcheon, 1995, p. 97). However, magical realist texts are generally perceived in tandem with postcolonial literature. For Homi Bhabha (1990), it is "the literary language of the emergent post-colonial world" (p. 7). In other words, it becomes the language of decolonization with a capacity to empower the colonised people by enabling them to "imagine alternative narrative visions of agency and history" (Faris, 2004, p. 136). 
According to Stephen Slemon (1988), when magical realist texts imaginatively reconstruct the past, they also recuperate the forgotten and ignored pieces, "those elements pushed to the margins of consciousness by imperialism's centralizing cognitive structures" ( $p$. 16). Therefore, magical realism is both historical and political. Inherently a resistant genre, magical realism introduces histories that stand against the imposed official history. It is political because it aims to change history through a critical approach and with an attempt to ease the historical sufferings (Faris, 2004, p. 138). Thus, magical realist texts approach history not in a naïve way but with an agenda in a deconstructive manner.

Ishiguro's The Buried Giant is a magical realist novel. In his brief definition, Faris indicates that, in magical realism, the supernatural exists as an organic part of the fictional realm, which blurs the boundaries that separate realism and fantasy (2004, p. 1). The magical in Ishiguro's text appears as a natural and organic part of daily life, which does not invoke surprise, fascination, or incredibility. Faris also creates a strong affinity between magical realism and postcolonial literature because "the (magical realist) mode is multicultural in its very nature" and it "reflects ... the hybrid nature of much postcolonial society" $(2004$, p. 1). However, the postcolonial context of Ishiguro's text needs elaboration. First, The Buried Giant is a multicultural text in which the cultures of Britons, Saxons, and Romans, though in decay, are encountered. Secondly, there is a repressive regime governed by the Britons and, naturally, a repressed nation, the Saxons. Moreover, although the narratorial voice remains neutral towards the two nations, the Christian Britons in the novel marginalize the pagan Saxons as "savages," and "a great burden" (Ishiguro, 2015, p. 113). In other words, the Saxons become the Other in the text. Historically speaking, the general paradigm of colonial experience has been based on the meeting of the coloniser, who is alien to the colonised land, and the colonised, who is native to the colonised land. Again, historically, the Britons are the native or the indigenous people of the British islands while the Saxons set foot on the island as foreign barbaric invaders. When considered from this historical perspective, the text stands against the general paradigm of the colonial experience. In this context, colonial matters appear metonymically in the text (Slemon, 1988, p. 12) as it creates constant colonial tensions such as assimilation, coercion, silencing, alterity, exploitation, and identity problems.

Ishiguro benefits from the potential of magical realism within this metonymic colonial context that enables him to cover his favourite themes: memory, and history. 
This generic potential also makes room in his text for an imaginative reconstruction of one part of British history, a reconstruction that exhibits discontinuity, rupture, and break. Moreover, the reconstructed version, in a postmodern gesture, helps the reader question the fixities of the continuous history, the possibility of objective and singular history. It highlights contingency and undermines causality, which is common to magical realism. As the most apparent generic quality, magic is used to interrogate the established "realistic conventions of causality, materiality, motivation" (Zamora and Faris, 1995, p. 3). In this context, magical realist handling of history overlaps with Foucauldian archaeological analysis. It is also in the same context that Foucault is considered "anti-historical," as he rejects "linear historical causality between events and epochs" and favours "a history based upon the discontinuities between dominant figurative structures operating in human consciousness" (Munslow, 2006, p. 129). For Foucault, as the product of the Enlightenment philosophy, continuous history serves for uniformity and totality, which also promises that the subject will eventually take everything under his control. In The Archaeology of Knowledge (2002), Foucault remarks that:

Continuous history is the indispensable correlative of the founding function of the subject: the guarantee that everything that has eluded him may be restored to him; the certainty that time will disperse nothing without restoring it in a reconstituted unity; the promise that one day the subject - in the form of historical consciousness - will once again be able to appropriate, to bring back under his sway, all those things that are kept at a distance by difference, and find in them what might be called his abode. (p. 13)

Continuous history aims to achieve a total history, governed by reason, committed to an ideology, and woven around a centre. Through causality, it produces a seamless grand narrative eliminating discrepancies, silencing diverse and conflicting voices. As opposed to the total history, Foucault points out a "new history" (2002, p. 11) in which he "suspends" the notions of tradition, the sovereignty of consciousness and subject, development and evolution, spirit, as the essential components of the continuous history (2002, pp. 13-26). Foucault's main concern is not to examine a totality "but a set of conflicting discursive frameworks" (Mills, 2003, p. 63). These frameworks also determine what could be said, thought and circulated, and what could pass as a knowledge in a certain period. In this context, he introduces the term épistèmé, which he defines as 
"the total set of relations that unite, at a given period, the discursive practices that give rise to epistemological figures, sciences, and possibly formalized systems" (2002, p. 211). In other words, an épistèmé is"the body of knowledge and ways of knowing which are in circulation at a particular moment" (Mills, 2003, p. 28). For Foucault, discontinuities and ruptures occur in history with a change in the épistèmé, which is sudden and not called forth. This change is not gradual nor accumulative and it does not pave the way for the next stage.

Specifying the épistèmé as such, Foucault aims to lay bare "the strangeness of our current state of knowledge and to question the way that we think, and the conceptual tools which we use to think with" (Mills, 2003, p. 64). At this point, Foucauldian historical analysis again overlaps with the magical realist approach to history. Both are critical against any attempt to totalize or synthesize history. While the former holds that historical categories are open to change and interpretation, in a never-ending process, depending on the available knowledge (Munslow, 2006, p. 130), the latter mounts a stiff resistance by fictionalizing and editing official historical narratives (D'haen, 1997, p. 289). As a variant of continuous history, official history, which is informed by state ideology, functions to stabilize and secure social codes to be able to demonstrate a nation in progress. Magical realist texts, such as Ishiguro's The Buried Giant and Rushdie's Midnight's Children (1981), work on official histories to find gaps and silent points to unveil their discontinuous nature.

What is at stake here is the "ideological use of history by which one tries to restore to man everything that has unceasingly eluded him," and through which man is able to find a shelter safer than "myths, kinship systems, languages, sexuality, or desire" (Foucault, 2002, p. 15). These contingent categories listed by Foucault may not be safe because they defy reason and have the potential to thwart classification, domestication, or taming attempts of man to tailor them to his needs or ideological agenda. As a resistant and political genre, and as a crucial weapon for a "war of cultural recovery" (Hart, 2005, p. 16), magical realism incorporates myths, legends, folktales, and oral narratives into their narratives. This incorporation necessitates the restoration of the lost historical narratives preserved in "local' or 'indigenous' myths and religions that are not those of the 'West'"' (Hart, 2005, p. 16). These myths, moreover, are not used for their inherent truth value but turn into a potent tool for writers to communicate their views (Shaw, 2005, p. 46). Myths are valuable for magical realism since, firstly, supernatural elements are an inherent part of these stories and, secondly, working on an already 
known story, writers can focus on their messages. Moreover, the desired effect on readers increases when these myths are presented in a deconstructive or revisionist way. This revisionism may even be more impressive when mythical elements are blended with historical facts, enabling authors to introduce their versions of history against the official one.

\section{Ishiguro's The Buried Giant}

Yugin Teo reports that Ishiguro is also of the opinion that novelists should operate on myths to contest the realist conventions and to create "a fabulous world" to subvert that myth $(2014$, p. 100). In his Nobel Lecture in 2017, after appreciating the "international fiction" of Salman Rushdie and V. S. Naipaul, Ishiguro states that, in his early career, he wanted to create a mythical England that surpasses borders of culture and language, and that is familiar to everyone in the world $(2017$, p. 8$)$. In the same lecture, he also openly expresses his admiration for the British people of the 1960s as his Japanese family was welcomed into the society even though the two nations had fought against each other in the Second World War. This case and his later visit to Auschwitz, he points out, aroused his curiosity about the nature of memories, especially national memories. What he wonders is how these memories are forgotten or remembered, which also leads him to difficult questions such as whether forgetting could be used to prevent "cycles of violence" and whether order and peace could be achieved through "wilful amnesia and frustrated justice." (2017, p. 11). The idea of cyclical violence can be associated with continuous history as they both imply causality. On the other hand, forgetting naturally stops the cyclical movement; in other words, it stops violence breeding violence. Therefore, forgetting may serve discontinuous history well, enabling the change in the set of knowledge that designs possible discourses or statements in a specific period.

What may have impressed Ishiguro in his early years in England could be the discontinuity of enmity between the two nations after the war, and what disappoints him in the present, particularly in the political context of Brexit discussions, is the proliferation of the extreme conservatism and rising racism that moves "beneath our civilised streets like a buried monster awakening," (Ishiguro, 2017, p. 15). Ishiguro's observation of the post-war years as a period of peace and tranquillity and the years following the fall of the Berlin Wall as a period of increasing violence and turmoil can be cited as instances of transformation or discontinuity in Foucauldian terms. In The 
Buried Giant, he adopts the "buried monster" analogy and introduces a powerfully revisionary, deconstructive and discontinuous history. To this end, and in line with his intent to introduce a mythical England well-known to everyone, which might be credited to his "cosmopolitan perspective" and "transnational uncertainty" (Vernon and Miller, 2018, p. 68), he borrows elements from Arthurian literature.

The interest in Arthurian literature is not peculiar to Ishiguro. For centuries, the stories revolving around King Arthur and his knights of the Round Table have been culturally reproduced in different forms, adapted for different mediums, and ideologically modified to serve different ends (Pearsall, 2005). While these stories provided an invaluable source for the medieval romance tradition, postmodern literature with its obvious interest in history has revisited medieval texts like Geoffrey of Monmouth's pseudohistorical Historia Regum Britanniae (History of the Kings of Britain, 1136) and romances like anonymous Sir Gawain and the Green Knight and Thomas Malory's Le Morte d'Arthur (1485). In addition to this literary interest, these stories have attracted a nascent critical interest classified as medieval postcolonial studies (Lampert-Weissig, 2010; Lynch, 2017, pp. 307-320). This approach extends colonial history to underscore the potential contributions of medieval texts to our perception of "colonial processes" (Lampert-Weissig, 2010, p. 1). In this context, according to Lynch, "the long enduring, diverse and multi-centred linguistic and cultural range of Arthur's legend can be plotted against national, regional and global shifts in power and peoples over many centuries, in a way that shadows the long history of colonialism" $(2017$, p. 307). This is possible because the legend lays the necessary historical foundations for British national identity, taking it as back as to Troy, and functions as a primal example of the nation's imperial spirit (Pearsall, 2005, p. 8). In this way, the legend provides the nation with both a prerequisite glorious past and an archetypal and unifying leader whose expansionist operations inspire British imperialism. While Arthurian literature has praised colonial expeditions, it has also hinted at "the problems of empire for both master and subject groups and made visible within its complex narratives aspects of resistance to colonial control" (Lynch, 2017, p. 317). This resistance can be observed within political themes like territorial expansion, border conflicts, the exercise of power and control over morally inferior races.

Lynch associates the current critical interest in Arthurian romances with the rising obsession "with border security and fantasies of pure national identity" (2017, p.318). This may be one of the reasons for Ishiguro's turn to the medieval Arthurian romances. 
Ishiguro is outspokenly against "Brexit", which he defines as a "myopic process" undermining the ideal of "living in near-borderless friendship" (2016, p. 1). For him, Brexiters base their arguments on "uncontrolled immigration" and "sovereignty" (2016, p. 3). Vernon and Miller believe that the political context of the Buried Giant becomes more meaningful when put into Brexit discussions, which may disturb the peace in Europe and call for a reconsideration of British identity $(2018$, p. 70$)$. They argue that:

Ishiguro produces a novel that deconstructs the nature of cosmopolitanism and refigures it through paradigms that precede the logics that produced the current vision of a unified Europe. ... His book attempts to recover the strangeness of medieval English romance's use of migration and conquest narratives to imagine British sovereignty. The patterns of movement and interpenetration of spaces that Ishiguro recovers militate against current claims of an always-already British nation. (2018, p. 70)

In his Anatomy of Criticism, Northrop Frye indicates that "in every age, the ruling social or intellectual class tends to project its ideals in some form of romance" (2000, p. 186). Likewise, Pearsall suggests that medieval romances are alluring to us because they "[embody] the social and political attitudes, needs and fears of their authors, patrons and audiences and the class to which they belonged" (2005, p. 23). This political potential of Arthurian romance can be cited as another reason for Ishiguro's interest in the genre. While medieval romances were set in "a distant past" but reflected their contemporary politics, like relegation of Arthur from "a divinely endorsed super-king" to the position of the "first among equals" in Anglo-Norman romances to secure the position of a "newly planted aristocracy" (Pearsall, 2005, p. 24), The Buried Giant is also set in a distant past, within a magical realist mode and metonymic colonial context, but discusses $21^{\text {st }}$-century politics, particularly immigrant crisis, rising nationalism, and border security.

The complexity of such political issues, of course, requires the subversion of medieval romance in a postmodern gesture. While keeping certain conventions like"the episodic structure,"'quest motive,"'adventure" and the supernatural elements, Ishiguro subverts the Arthurian romance by distancing the time of the story and the narrative further, by modifying the setting and characterization, and by denying his reader an exact and happy closure (Sönmez Demir, 2020, pp. 119-139). However, the two most remarkable deviations from traditional romance are the portrayal of King Arthur and the 
understanding of history. The conventional and established portrayals of King Arthur depict him as a brave, legendary, and unifying warrior-king whose exploits substantially contributed to the forging of the British national identity. Ishiguro deconstructs that archetypal character by introducing a trickster king who breaks his oath and commits genocide. Thus, Ishiguro's Arthur violates the chivalric code of honour, propagated by the medieval romance, and executes a political, dishonest, and horrifying manoeuvre to strengthen his regime. The novel also dismantles the sense of history in the medieval romance tradition. While history in such romances is cyclical and, overall, displays the gradual and evolutionary building of nationhood in a continuous form, Ishiguro's text introduces a discontinuous history. In this way, the text lays bare the ruptures and the contingency in nation-building, which, in the context of contemporary politics, enables Ishiguro to demonstrate the fluidity of national identities and question the validity of the borders separating them.

The novel brings together elements from the actual and the mythical past of Britain. On the very first page of the novel, the narrator indicates that it was a time when the old Roman roads had become "broken or overgrown" and "icy fogs hung over rivers and marshes, serving all too well the ogres that were then still native to this land" (Ishiguro, 2015, p. 3). In this realm, where the supernatural and the familiar coexist, Britons and Saxons live harmoniously. It is later understood that King Arthur stopped all the fighting and brought peace to this land, thanks to a grey mist covering the country which robbed the people of their memories, thus, breaking their connection with their past. The source of this grey mist is a spell that Merlin casts on a dragon, Querig. As long as the dragon breathes, the spell continues to confine the people to a perpetual present. However, as the dragon gets older, the power of the spell diminishes, which brings fragments of memories and confused recollections back. It is, therefore, an old Briton couple, Beatrice and Axl, who decide to leave their warren-like settling to take the long-delayed journey to reunite with their son.

During the journey, Beatrice and Axl meet three other travellers, whose fates become entwined with theirs. Edwin, a Saxon boy bitten by a dragon; Wistan, a skilled Saxon warrior from the fenlands of the east with orders from his king to slay the dragon; Sir Gawain, from the Arthurian legend, though defined as a "whiskery old fool" (Ishiguro, 2015, p. 113), a gallant knight with a mission to protect the dragon. On their journey, Beatrice and Axl also learn that Arthur tricked the Saxons into a treaty that guaranteed neither side would attack the villages during the battle. However, Arthur's men, under 
his order, raided these villages and slaughtered the defenceless Saxon women, children, and elders. Then, with the enchanted dragon's breath, Arthur wiped out all memories to prevent future vengeance and to protect the peace. Yet, Arthur has been dead for a long time and there are now left only a group of monks, who tend the ailing dragon, and Sir Gawain, who has vowed to defend Arthur's ill-gained legacy and order. Eventually, Wistan dramatically defeats Sir Gawain, kills the dragon, and breaks the spell, which restores all lost memories. With the restoration of memories, at the individual level, the couple fears that their union may be ruined with the emergence of an unwanted memory, but at the collective level, they fear that more atrocities will be committed by the two nations driven by the desire for vengeance. In other words, when memories are restored, a transformation occurs in the body of knowledge (épistèmé) that designates both collective and individual relations, which, consequently, signals a rupture or a break in history.

There are three definitive moments of discontinuity in the novel. The first one, though very briefly mentioned, occurs with the departure of the Romans from the island; a discontinuity that is between civilization and barbarism. The symbols of Roman civilization fade away as their roads and their splendid villas become "broken or overgrown" decaying "into wilderness" (Ishiguro, 2015, p. 3). The narrator also admits "that at a time when magnificent civilisations flourished elsewhere," these people were barely "beyond the Iron Age" (Ishiguro, 2015, p. 4). While the Britons lived in "sprawling warren" or "shelters, many of them dug deep into the hillside," Saxon villages were filled with an unpleasant odour from "piles of putrefying meat as offerings to their various gods" (Ishiguro, 2015, pp. 4-54). The remnants of the Roman civilization can only be observed in the decaying buildings and the religious practices, and in the martial skills of the Britons. The second, and the most important discontinuity in the novel is the wiping away of memories with the magic placed on the dragon's breath by King Arthur. Thanks to the magic, the Saxons and the Britons lead their lives in peace, though in an amnesiac condition, locked in a perpetual here and now. The last discontinuity, or rupture, takes place when the dragon is slain, and memories are restored.

Memories might be defined as the cognitive containers of information crucial to the survival of human beings. When required, the information is retrieved, cognitively processed, and transformed into knowledge. Thanks to this faculty we can communicate, drive cars, hunt animals, or find our way home. In the novel, the ordinary course of daily life continues, which implies that the magical mist does not erase every memory, 
but a particular segment of them. Endel Tulving (1972), a prominent Canadian psychologist, groups memory under two categories as semantic memory and episodic memory. The former contains facts and general knowledge, where, for instance, language is stored; the latter includes "temporally dated episodes or events" (Tulving 1972, p. 385). While episodic memory is prone to "transformation and loss of information," semantic memory is much protective and stable in this sense $(1972$, p. 386). This is because episodic memory has "autobiographical elements" and is related to "personal experience" (Tulving, 1972, pp. 385-6). Thus, its content may change with the entrance of new input. It is fair then to suggest that the dragon's breath directly affects episodic memory as the set of knowledge crucial for survival, like linguistic skills, stored in semantic memory which remains intact.

Tulving discerns three stages of episodic memory; "conscious awareness of the personal past; acquisition and storage of information; and conversion of the information into behaviour" (1989, p. 4). In the novel, the magical mist does not let anyone remain conscious of their personal past. The narrator explains that it just does not "occur to these villagers to think about the past-even the recent one" (Ishiguro, 2015, p. 7). So long as the dragon breathes, they also cannot acquire or store new information. For instance, when a girl from the village is lost, they stop the search and forget about the missing girl when a wren-eagle attracts their attention. Beatrice also remarks that "[i] t's queer the way the world's forgetting people and things from only yesterday and the day before that" (Ishiguro, 2015, p. 19). Naturally, without an input of new information, patterns of knowledge and behaviour cannot change, which also makes a change in the épistèmé impossible.

Regarding episodic memory, Tulving further claims that, when represented, a recollected moment refers to "the rememberer's personal knowledge of his personal identity" (1971, p. 389). The couple leaves their village to find their son, but they cannot remember why he left in the first place. They even wonder whether there was "ever a time before [they] knew one another" (Ishiguro, 2015, p. 45). Although Axl has difficulties in retrieving information related to his personal past and his identity, he is himself surprised how keenly and technically he can observe and comment on the combat scene between Wistan and a Briton soldier (Ishiguro, 2015, p. 122). That Axl is able to decode the movements of the combatants suggests that his semantic memory is unharmed by the spell as he can retrieve general facts about combat skills. Axl may appear like an old and ordinary villager, but in the past, he was a high-ranking officer 
in Arthur's rule, known as "the Knight of Peace," which explains how he happens to acquire this knowledge (Ishiguro, 2015, p. 232). This also suggests that Arthur's spell works systematically on memories, erasing those that would threaten his political order and keeping those that are required for the continuity of life. In other words, Arthur colonises and disciplines the mental landscapes of his subjects and turns them into docile bodies.

By establishing this dominion on this mental space, Arthur is able to guide behavioural patterns and exercise complete power by both regulating and putting a limit on the available set of knowledge. While discussing the Assyrian king as a tyrant, Foucault indicates that:

By the fact of holding power, the king and those around him held a knowledge that could not and must not be communicated to the other social groups. Knowledge and power were exactly reciprocal, correlative, superimposed. There couldn't be any knowledge without power; and there couldn't be any political power without the possession of a certain special knowledge. (2001, p. 31)

King Arthur and those around him, like Sir Gawain, hold this precious knowledge; people's personal past, personal experiences, and episodic memories which are basic means for the people to identify themselves. For Foucault, the means of power are threatening because they appear neutral and politically invisible (Gordon, 2001, p. xv). The mist that covers the whole country may be visible, but its effect is unknown, and thus invisible, to the people. It has a neutral function as it affects both the Saxons and the Britons, leaving unaffected only those in power with this special knowledge. Moreover, the mist provides a powerful form of political domination which combines structures of knowledge and power. It is also in concordant with Foucault's argument that the mind, rather than the body, has become "the object of control" in modern capitalist countries (Poster, 1984. p. 80).

In the novel, King Arthur, as the ultimate symbol of power and the coloniser of the minds, interrupts or breaks history; in other words, makes a temporal dislocation. By robbing his people of their memories, Arthur destroys their subject positions transforming them into objects. As the Saxons forget the atrocity and the slaughter, they lose their will to power, their national identity. That is why the Saxon warrior Wistan, who is 
immune to the dragon's spell, wants to kill the dragon. When the mist is lifted, the Saxons will be able to remember who they are, restore their historical consciousness, claim their subject position, and will ask for revenge.

Arthur creates a discourse of brotherhood and even after his death, the remnants of his power try to protect it, as in Sir Gawain, or the monks in the monastery who feed the dragon. Gawain is adamant that peace would be impossible "without this shedragon's breath" and is pleased that "old foes" have become "cousins" (Ishiguro, 2015, p. 311). However, Wistan does not believe that a peace "built on slaughter and a magician's trickery" can prevail eternally (Ishiguro, 2015, p. 312). His arrival in this land coincides with the waning power of the Arthurian system. As the dragon grows old, the power of her magic diminishes, enabling people to recollect memories.

When people begin to retrieve information from their episodic memories, they inevitably use this information to produce new knowledge and new patterns of behaviour. In other words, the stage is ready for another historical discontinuity, as King Arthur has been dead for years and Sir Gawain is way beyond his young competent years. Even Horace, Gawain's battle horse, is wearied with carrying Gawain's armour for all those years (Ishiguro, 2015, p. 113). On the other hand, Wistan, who demonstrates "a natural authority," is a complete threat to the existing system of power (Ishiguro, 2015, p. 57). Moreover, he is a gifted warrior who can "withstand strange spells," which makes him immune to the mist (Ishiguro, 2015, p. 308). As a child, he was trained by the Briton masters, which enables him to exist as a dissident in the Arthurian power system as well. Alan Lupack suggests that Wistan reminds Beowulf both by "[killing] an ogre and [bringing] his shoulder and upper arm," and by being on a quest to kill the dragon, which emphasizes the conflict between "the Anglo-Saxon world of Wistan and the British world of Arthur" $(2015$, p. 118). The actual course of historical events informs that the former would eventually be victorious over the latter. The novel also implies this historical shift in power by playing the powerful and young Wistan against the old and weary Gawain.

According to Foucault, historiography has the power to eradicate historical differences and to introduce a new interpretation of the present. This bestows a special power on the historian as he becomes the controller of the past and modifier of the present (Poster, 1984. p. 76). Within this sense, the power shifts from King Arthur to the Saxon warrior Wistan, and the role of the historiographer is also handed over to the Saxon. 
As the ultimate show of his will and power, Wistan slays the dragon and transforms both the past and the present:

The giant, once well buried, now stirs. When soon he rises, as surely he will, the friendly bonds between us will prove as knots young girls make with the stems of small flowers.... [Our] armies will grow larger, swollen by anger and thirst for vengeance. For you Britons, it'll be as a ball of fire rolls towards you. You'll flee or perish. And country by country, this will become a new land, a Saxon land. (Ishiguro, 2015, p. 324)

Once the dragon is slain, all episodic memories are restored. Wistan's quest ends by killing the dragon, a theme which is "the central form of quest-romance" (Frye, 2000, p. 189). Dragons are important in romance tradition as they are the guards of invaluable wealth, which may ideally symbolize "power and wisdom" (Frye, 2000, p.193). What Querig protects is clearly associated with both power and wisdom. The episodic memories harbour the wisdom of the past that has the potential to condition the political power of the present. The survival of the Arthurian regime depends on the subjugation of that wisdom. However, the Saxon claim to sovereignty and power could only be possible through the restoration of it.

The restoration of memories does not only affect the power relations at the collective level; its effect can also be observed at the individual level. Until the restoration of their memories, Axl appears apologetic towards Beatrice for a past deed, though he cannot remember exactly what. Drawing from her confused and uncertain recollections, Beatrice repeatedly accuses $A x I$ of leaving her for a younger woman in the past. She even claims that their son left home because he did not want to be at home with Axl. Therefore, Beatrice seems to have the upper hand and assumes the dominant role. She asserts her superiority and dominance in terms of loyalty and morality by degrading her husband as the adulterer. However, there emerges a shift in the dynamics of their relationship when the spell is broken. Beatrice realizes that she is "the one to fear most the mist's clearing" because she is the one who committed adultery and caused the departure of their son, who later died in a plague (Ishiguro, 2015, p. 307). Thus, the re-emergence of the knowledge of infidelity unsettles their relationship.

The restoration of memories can also be explained by what Foucault specifies as "an insurrection of subjugated knowledges" (1980, p. 81). By subjugated knowledges, he 
means both"the historical contents that have been buried and disguised in a functionalist coherence or formal systemisation," and "naïve knowledges" which "have been disqualified as inadequate to their task or insufficiently elaborated" (1980, pp.81-82). One cannot reveal these knowledges under "the tyranny of globalising discourses with their hierarchy," like Marxism or liberalism (1980, p.83). Only by abandoning these totalizing and globalizing discourses can one observe ruptures and breaks within history and, only by virtue of this can one have access to the margins of knowledge.

Within this domain of knowledge, Foucault assigns an important role to the local memories as they enable the construction of "a historical knowledge of struggles" (1980, p.83). By abandoning totalizing or globalizing discourses and by conducting genealogical research on the ruptures, discontinuities, or breaks in history, it is possible "to emancipate historical knowledges from that subjection" so that they can be used in the "struggle against the coercion of a theoretical, unitary, formal and scientific discourse" (Foucault, 1980, p.85). Trying to read history against the totalizing discourses, or reading them against the grain, may start with a direct focus on the margins which have been neglected. The dragon's breath casts a veil over the local memories of these people and marginalizes them. In other words, Arthur subjugates these precious memories which are loaded with historical knowledge. $\mathrm{He}$, thus, manages to construct a unifying but also a totalitarian political power. When Wistan defeats Sir Gawain and slays the dragon, he removes that veil and sets these memories free. This also announces the end of Arthur's totalitarian regime.

This does not, however, mean that readers may enjoy a proper closure as in romances. Discontinuous narratives of history do not provide neat endings as these endings suggest a beginning and a conclusion, a logical accumulation, and causality. According to Vernon and Miller, the novel "refuses to undo the spell of wonder that it casts over its characters or its readers" by not revealing whether it "uses the [the dragon's death] to signal its departure from myth and entrance into something more closely approaching history" (2018, p. 84). On the other hand, Catherine Charlwood expresses that "Ishiguro's text resists closure because there is no good answer" to the posed questions like whether forgetting could stop violence and whether nations could stand without memories (2018, p. 37). What is obvious is "the fragility of national identity" (Charlwood, 2018, p. 37). However, the political cannot exist without the ideal of, and the hope for, change. If we are to assume that The Buried Giant creates a political context to discuss current politics regarding national identity and border security, we should be able to detect a 
symbol of hope, no matter how faint it is. Wistan kills the dragon so that the memory of Arthur's massacre will be revived. This revival will incite hatred in the Saxons against the Britons, which will also restore Saxon national unity. Although Wistan appears as a resolute warrior in completing his tasks, he admits towards the end that he is "enfeebled" as he has spent a long time among the Britons and feels shame that "a part of [him] turns from the flames of hatred" (Ishiguro, 2015, p. 324). That is why he wants to transmit this hatred to Edwin:

It was Britons under Arthur slaughtered our kind. It was Britons took your mother and mine. We've a duty to hate every man, woman and child of their blood. So promise me this. Should I fall before I pass to you my skills, promise me you'll tend well this hatred in your heart. (Ishiguro, 2015, p. 264)

Edwin is apparently perplexed by the gravity of Wistan's dictate:"I don't understand, warrior. Must I hate a Briton who shares with me his bread? Or saves me from a foe as lately did the good Sir Gawain?" (Ishiguro, 2015, p. 264). When Edwin is bitten by a dragon, the Saxon villagers, his own kinsmen, want to kill him as they superstitiously believe that he will also turn into a fiend. As Axl and Beatrice, and later Sir Gawain, escort him to safety, an affinity develops between Edwin and the other Britons. In other words, Edwin and Wistan's relationship with the Britons at the individual level turns them into, in a way, hybrid characters, which diminishes the power of racial hatred. As the group shares experience, exchanges food, and develops a sincere concern for the wellbeing of each other, they can see beyond the national identities. For Edwin, Axl and Beatrice are not primarily Britons but human beings who have guarded and shared their food with him. This implicit stress on hybridity may reveal the faint hope that Ishiguro cherishes. By going back to Arthurian times, Ishiguro reminds his British readership that the British national identity is the amalgamation of different nations and stresses that this identity has always been a hybrid one. The idea of a pure national identity is just a fantasy, for which the world has paid a great price. Therefore, rather than forgetting, the novel suggests that acknowledging hybridity, or conceding that we have similarities as well as differences may pave the way for forgiveness.

\section{Conclusion}

In a metonymic colonial context and by using the generic potentials of magical realism, Ishiguro introduces a discontinuous history. In this history, the coloniser (Arthur) 
uses magic as a coercive power tool to erase people's past, which creates a transformation and, hence, a discontinuity. Thereby, he silences and pacifies the people. By assuming the role of a historiographer, the coloniser rewrites the past and gives a new shape to the present. The history he writes is a singular one that neglects those in the margins. With a change in the épistèmé, that is, when the episodic memories are restored, there occurs another discontinuity in which the discursive power is transferred from the coloniser (Arthur) to the colonised (the Saxon warrior). Lost voices, discarded fragments, and the set of knowledges relegated to the margins are thus recuperated. However, Wistan predicts that the colonial tensions such as assimilation, coercion, and exploitation will continue in a different form. Wistan slays the dragon so that his people could acquire historical consciousness, a prerequisite for nation-building. The destruction of the dragon awakens another buried monster, the Saxons' demand for vengeance. The retribution they seek against the Britons will bring more atrocities, agonies, and sorrows.

Foucault's archaeological history may stem from his curiosity about "these transformations which do not correspond to the calm and continuist image" (1980, p. 112). Similarly, in his Nobel Lecture, Ishiguro states that his generation was optimistic and believed in the possibility of "a happy conclusion" since they had witnessed their parents "transform Europe from a place of totalitarian regimes, genocide and historically unprecedented carnage to a much-envied region of liberal democracies living in nearborderless friendship" (2017, p. 14). He regards these times as lost opportunities. In this context, The Buried Giant leads to greater questions regarding history. For instance, how can man handle the crimes of the past? How can humanity deal with Rwanda or Bosnia? Or is there a way to come to terms with the atrocities perpetrated by humanity all over the world? Sir Gawain, in the novel, admits their slaughter of the innocent but claims that this misdeed was performed for the greater benefit of the people. "A pleasant green carpet" now covers the victims and the traces of that slaughter are well hidden from the knowledge of the new generation, which prevents further bloodshed (Ishiguro, 2015, p. 311). Therefore, Sir Gawain wants to defend the status quo and dissuade Wistan from killing the dragon:

I beg you leave this place, and let Querig do her work a while longer. Another season or two, that's the most she'll last. Yet even that may be long enough for old wounds to heal for ever, and an eternal peace to hold among us. ... Leave this country to rest in forgetfulness. (Ishiguro, 2015, p. 311) 
The narratives of continuous history may function to legitimize the present as the best possible culmination of the past events. The present is justified and rationalized by these narratives that establish cause and effect relationship. For this sake, such historical narratives tend to ignore the discrepancies or contingencies that violate the smooth flow of history, which, consequently, produces a monolithic and totalitarian history. Those who hold the power to write histories also decide on what to include (remember) or exclude (forget). When Gawain urges Wistan to leave the country in that amnesiac condition for keeping the peace, he sounds genuine. However, the complexity of the situation is laid bare when Wistan asks: "How can old wounds heal while maggots linger so richly?" (Ishiguro, 2015, p. 311). In this way, the novel examines whether oblivion or subjugation can help to overcome past agonies and sorrows. It does not propose a clear-cut solution to this convoluted and fundamental question. However, one of the apparent implications is that human history is full of deep sorrows, extreme agonies, and unpunished crimes. Another one is that a direct confrontation with and a fair judgment of the past are preconditions if we are to maintain human dignity, regardless of ethnic and religious background, social class, or sexual orientation. This may be achieved through an overall comprehension of human history by including the margins, recuperating the lost voices, and observing the ruptures and the discontinuities.

If examined within the context of contemporary political issues, such as increasing nationalism, immigration, and border security, the novel seems to be content with just pointing out the problem. However, between the lines, Ishiguro provides the reader with a glimmer of hope in his characterization of Edwin who represents the coming generations. The text implicitly remarks that the friendship that develops at the individual level between the Saxon Edwin and his Briton guardians, which hybridizes him, can be deployed to overcome enmities at the collective level. Moreover, by both exploiting and subverting medieval romances, narratives that provide mythical and historical foundations for the imperial British identity, Ishiguro underscores the constructed nature of national identities. As a transnational author, this is Ishiguro's warning to the people who are carried away by the dangerous illusion of a pure national identity. It is also his foregrounding of sincere individual relations that can cease collective hostilities and can bring along forgiveness. 
Peer-review: Externally peer-reviewed.

Conflict of Interest: The author has no conflict of interest to declare.

Grant Support: The author declared that this study has received no financial support.

Hakem Değerlendirmesi: Dış bağımsız.

Çıkar Çatışması: Yazar çıkar çatışması bildirmemiştir.

Finansal Destek: Yazar bu çalışma için finansal destek almadığını beyan etmiştir.

\section{References}

Bhabha, H. (1990). Introduction: narrating the nation. In Homi Bhabha (Ed.), Nation and Narration (pp. 1-7). London: Routledge.

Charlwood, C. (2018). National identities, personal crises: Amnesia in Kazuo Ishiguro's the buried giant. Open Cultural Studies, 2, 25-38. https://doi.org/10.1515/culture-2018-0004

D’haen, T. L. (1997). Postmodernisms: From fantastic to magic realist. In H. Bertens \& D. Fokkema (Eds.) International postmodernism: Theory and literary practice (pp. 283-293). Amsterdam: John Benjamins Publishing.

Esen, Ö. (2018). pp. 7-20; Recovering memories and reconstructing realities: Magical realism and Kazuo Ishiguro's The buried giant. (Master's thesis, Pamukkale University). Retrieved from http://acikerisim.pau.edu.tr/xmlui/ bitstream/handle/11499/27617/\%C3\%96zg\%C3\%BCr\%20Esen.pdf?sequence=1\&isAllowed=y

Faris, W. B. (2004). Ordinary enchanments: Magical realism and the remystification of narrative. Nashville: Vanderbilt University Press.

Foucault, M. (1980). Power / knowledge: Selected interviews and other writings: 1972-1977. (C. Gordon, Ed.). New York: Pantheon Books.

-----. (2001). Power: The essential works of Foucault, 1954-1984. (Vol. 3). (R. Hurley \& J. D. Faubion \& P. Rabinow, Eds.). New York: The New Press.

-----. (2002). Archaeology of knowledge. (A. Sheridan, Trans.) London \& New York: Routledge.

Frye, N. (2000). Anatomy of criticism: Four essays. Princeton \& Oxford: Princeton University Press.

Gordon, C. (2001). Introduction. In R. Hurley \& J. D. Faubion \& P. Rabinow (Eds.), Power (The essential works of Foucault, 1954-1984 (pp. xi-xli). New York: The New Press.

Hart, S. M. (2005). Introduction: Globalization of Magical Realism: New Politics of Aesthetics. In S. M. Hart \& W. Ouyang (Eds.), A companion to magical realism (pp. 1-12). Woodbridge: Tamesis.

Hutcheon, L. (1995). A poetics of postmodernism. London: Routledge.

Ishiguro, K. (2015). The buried giant. London: Faber.

------. (2016, July 1). Kazuo Ishiguro on his fears for Britain after Brexit. Financial Times. Retrieved from https:// www.ft.com/content/7877a0a6-3e11-11e6-9f2c-36b487ebd80a 
----. (2017). Nobel lecture (pdf). Retrieved from https://www.nobelprize.org/uploads/2018/06/ishigurolecture_en-3.pdf

Lampert-Weissig, L. (2010). Medieval literature and postcolonial studies. Edinburgh: Edinburgh University Press.

Lynch, A. (2017). Post-colonial studies. In L. Tether and J. McFadyen (Eds.), Handbook of Arthurian romance: King Arthur's court in medieval European literature (pp. 307-320). Berlin: De Gruyter.

Lupack, A. (2015). [Review of the buried giant]. Arthuriana, 25(3), 118-120. Retrieved from http://www.jstor.org/ stable/24643534

Mills, S. (2003) Michel Foucault. London \& New York: Routledge.

Munslow, A. (2006) Deconstructing history. $2^{\text {nd }}$ Ed. London \& New York: Routledge.

Pearsall, D. (2005). Arthurian romance: A short introduction. Oxford: Blackwell.

Poster, M. (1984). Foucault, Marxism and history: Mode of production versus mode of information. Oxford: Polity Press.

Shaw D. L. (2005). The presence of myth in Borges, Carpentier, Asturias, Rulfo and García Márquez. In S. M. Hart \& W. Ouyang (Eds.), A companion to magical realism (pp. 46-54). Woodbridge: Tamesis.

Slemon, S. (1988). Magic realism as post-colonial discourse. Canadian Literature, 116, 9-24. Retrieved from https://canlit.ca/full-issue/?issue=116

Sönmez Demir, Y. (2020) Kazuo Ishiguro's postmodern hypertexts: Generic reconfigurations in the Remains of the day, when we were orphans, and the buried giant. (Doctoral dissertation, Middle East Technical University). Retrieved from http://etd.lib.metu.edu.tr/upload/12625819/index.pdf

Teo, Y. (2014). Kazuo Ishiguro and memory. New York: Palgrave Macmillan.

Tulving, E. (1972). Episodic and semantic memory. In E. Tulving \& W. Donaldson (Eds.), Organization of memory (pp. 381-403). New York: Academic.

-----. (1989). Memory: Performance, knowledge, and experience. European Journal of Cognitive Psychology, 1:1, 3-26. dx.doi.org/10.1080/09541448908403069

Tutan, D. E. (2016). A hybrid discourse: From Latin American magic realism to the British postcolonial postmodern novel. Selçuk University The Journal of Institute of Social Sciences, 36, 38-50. Retrieved from http://dergisosyalbil.selcuk.edu.tr/susbed/article/view/1285/1079

Vernon, M., \& Miller, M.A. (2018). Navigating wonder: The medieval geographies of Kazuo Ishiguro's the buried giant. Arthuriana 28(4), 68-89. doi:10.1353/art.2018.0036.

Zamora L. P. and W. B. Faris. (1995). Introduction. In L. P. Zamora \& W. B. Faris (Eds.), Magical realism: Theory, history, community (pp. 1-11). Durham \& London: Duke University Press. 